\title{
Comparative bronchial responses to hyperosmolar saline and methacholine in asthma
}

\author{
L-P BOULET, C LEGRIS, L THIBAULT, H TURCOTTE
}

From the Centre de Pneumologie, Hôpital Laval, Ste-Foy, Quebec, Canada

ABSTRACT Airway responsiveness to inhaled methacholine and to ultrasonically nebulised hyperosmolar saline was compared in 20 asthmatic subjects. Each subject had two hyperosmolar inhalation tests and a methacholine challenge in random order at least 48 hours apart over a period of two weeks. Hyperosmolar challenge, carried out with doubling concentrations of saline from $0.9 \%$ to $14.4 \%$ to obtain a dose-response curve, was well tolerated by all subjects. The response to hyperosmolar saline-expressed as the $\mathrm{PO}_{20}$, the osmolarity inducing a $20 \%$ fall in forced expiratory volume in one second $\left(\mathrm{FEV}_{1}\right)$ was obtained in 16 of the 20 subjects and in each was repeatable to within one doubling concentration of saline. The peak bronchoconstrictor effect of hyperosmolar saline inhalation occurred at 3 minutes and its mean total duration $\left(\mathrm{FEV}_{1}<90 \%\right.$ of baseline) was 50 minutes. There was no significant correlation between the $\mathrm{PO}_{20}$ and the $\mathrm{PC}_{20}$ methacholine (the concentration inducing a $20 \%$ fall in $\mathrm{FEV}_{1}$ ). Thus by using a new method to obtain a quantitative airway response to inhaled hyperosmolar saline we found that the airway response to hyperosmolar inhalation differs from the airway response to methacholine.

The inhalation of hyposmolar or hyperosmolar solutions may induce bronchoconstriction in asthmatic subjects $^{1-3}$ and provides a new method to investigate non-specific bronchial responsiveness. It has been suggested that this type of bronchial provocation test may be useful in the diagnosis and evaluation of asthma ${ }^{4}$ and for studying the mechanisms of exercise induced asthma. ${ }^{56}$ The hyperosmolar inhalation test, however, has not been standardised and little is known about the mechanisms by which it induces bronchoconstriction.

Findlay and colleagues have shown that hyperosmolar stimulation can induce the release of histamine from human basophils. ${ }^{7}$ Both hypo-osmolar and hyperosmolar solutions of glucose and saline produced bronchoconstriction in patients with mild asthma, whereas an ion free iso-osmolar solution did not reduce expiratory flow rate. ${ }^{8}$ Pretreatment with nebulised sodium cromoglycate reduced the response to $3.6 \%$ saline, suggesting that chemical mediators may be released from mast cells in response to hyperosmolar challenge.'

Address for reprint requests: Dr Louis-Philippe Boulet, Le Centre de Pneumologie, Hôpital Laval, 2725 Chemin Ste-Foy, Sainte-Foy, Québec. Canada GIV 4G5.

Accepted 5 August 1987
There have been reports of some degree of correlation between the airway responses to different nonspecific stimuli, such as exercise and inhaled histamine, ${ }^{9}$ isocapnic hyperventilation of cold air and inhaled methacholine or ultrasonically nebulised water, ${ }^{10} 11$ and the inhalation of distilled water and exercise. $^{12}$ Little, however, is known about the relationship between the bronchial response to hyperosmolar solutions and other bronchoconstrictor stimuli.

This study was designed to develop a method to measure non-specific bronchial reactivity to hyperosmolar solutions in a dose-response manner, to verify its reproducibility, to examine tolerance to high concentrations of saline, and to compare the airway response to hyperosmolarity with the response to inhaled methacholine in the same subjects.

\section{Methods}

Twenty patients with asthma as defined by the American Thoracic Society (10 of them women), aged 17-48 years, took part to the study (table 1). Their asthma was mild to moderate, with $\mathrm{PC}_{20}$ values (provocative concentrations of methacholine giving a $20 \%$ fall in the forced expiratory volume in one second $\left(\mathrm{FEV}_{\mathrm{l}}\right)$ ) ranging from 0.19 to $6.73 \mathrm{mg} / \mathrm{ml}$. Asthma 
Characteristics of the subjects

\begin{tabular}{|c|c|c|c|c|c|c|c|c|c|c|c|c|}
\hline \multirow{3}{*}{$\begin{array}{l}\text { Subject } \\
\text { No } \\
1\end{array}$} & \multirow{3}{*}{$\begin{array}{l}\begin{array}{l}\text { Age } \\
(y)\end{array} \\
44\end{array}$} & \multirow{3}{*}{$\begin{array}{l}\text { Sex } \\
\mathrm{F}\end{array}$} & \multirow{3}{*}{$\frac{\text { Atopy }^{*}}{0}$} & \multirow{3}{*}{$\begin{array}{l}\frac{F E V_{1}}{(\% \text { pred })} \\
2 \cdot 25 \\
(74)\end{array}$} & \multirow{3}{*}{$\begin{array}{l}F V C \\
\text { (\% pred) } \\
3.45 \\
(88)\end{array}$} & \multicolumn{2}{|c|}{$\begin{array}{l}P C_{20} \text { methacholine } \\
(\mathrm{mg} / \mathrm{ml})\end{array}$} & \multicolumn{2}{|c|}{$\begin{array}{l}P O_{20} \text { saline } \\
(\mathrm{mmol} / \mathrm{l})\end{array}$} & \multirow{2}{*}{\multicolumn{3}{|c|}{$\begin{array}{l}\text { Current } \\
\text { medication }\end{array}$}} \\
\hline & & & & & & \multirow{2}{*}{$\begin{array}{l}\text { Test } 1 \\
0.66\end{array}$} & \multirow{2}{*}{$\begin{array}{l}\text { Test } 2 \\
0 \cdot 25\end{array}$} & \multirow{2}{*}{$\begin{array}{c}\text { Test I } \\
1091 \cdot 5\end{array}$} & \multirow{2}{*}{$\begin{array}{l}\text { Test } 2 \\
1167 \cdot 8\end{array}$} & & & \\
\hline & & & & & & & & & & $\mathbf{B}_{2}$ & $T$ & B \\
\hline 2 & 20 & $\mathbf{F}$ & 5 & $\begin{array}{l}2.89 \\
(89)\end{array}$ & $\begin{array}{l}4 \cdot 13 \\
(103)\end{array}$ & $2 \cdot 86$ & $1 \cdot 31$ & $>4610$ & $>4610$ & $\mathbf{B}_{2}$ & & \\
\hline 3 & 22 & $\mathbf{F}$ & 7 & $\begin{array}{l}2 \cdot 82 \\
(98 \cdot 6)\end{array}$ & $\begin{array}{l}3.47 \\
(98.5)\end{array}$ & $4 \cdot 34$ & 2.09 & 674.5 & 869.9 & $\mathbf{B}_{2}$ & & \\
\hline 4 & 19 & $F$ & 11 & $\begin{array}{l}2.77 \\
(82)\end{array}$ & $\begin{array}{l}3.62 \\
(97.8)\end{array}$ & 0.53 & 0.46 & $2737 \cdot 2$ & $3541 \cdot 1$ & $\mathbf{B}_{2}$ & & \\
\hline 5 & 21 & $\mathrm{~F}$ & 0 & $\begin{array}{l}3.67 \\
(107.9)\end{array}$ & $\begin{array}{l}4 \cdot 26 \\
(107 \cdot 7)\end{array}$ & $4 \cdot 5$ & $5 \cdot 28$ & $>4610$ & $>4610$ & $\mathbf{B}_{2}$ & $\mathrm{~T}$ & B \\
\hline 6 & 29 & $\mathbf{M}$ & 13 & $\begin{array}{l}3.60 \\
(81)\end{array}$ & $\begin{array}{l}5 \cdot 15 \\
(90 \cdot 5)\end{array}$ & 0.55 & & 680 & $584 \cdot 5$ & $\mathbf{B}_{2}$ & & \\
\hline 7 & 32 & $\mathbf{M}$ & 7 & $\begin{array}{l}3 \cdot 55 \\
(87 \cdot 4)\end{array}$ & $\begin{array}{l}4.78 \\
(92 \cdot 4)\end{array}$ & $2 \cdot 69$ & 1.09 & $1325 \cdot 3$ & $1249 \cdot 0$ & $\mathbf{B}_{2}$ & & \\
\hline 8 & 48 & $\mathbf{M}$ & 5 & $\begin{array}{l}2 \cdot 39 \\
(63 \cdot 9)\end{array}$ & $\begin{array}{l}4.55 \\
(89.9)\end{array}$ & 0.33 & 0.64 & $701 \cdot 0$ & 473.4 & $\mathbf{B}_{2}$ & $\mathrm{~T}$ & \\
\hline 9 & 43 & $\mathbf{M}$ & 0 & $\begin{array}{l}3.28 \\
(93.9)\end{array}$ & $\begin{array}{l}4.75 \\
(104 \cdot 8)\end{array}$ & $2 \cdot 06$ & 1.62 & $3217 \cdot 0$ & $2441 \cdot 7$ & $\mathbf{B}_{2}$ & $\mathrm{~T}$ & B \\
\hline 10 & 25 & $\mathrm{~F}$ & 8 & $\begin{array}{l}2.95 \\
(89 \cdot 6)\end{array}$ & $\begin{array}{l}3 \cdot 71 \\
(90 \cdot 3)\end{array}$ & $0 \cdot 23$ & 0.20 & $656 \cdot 6$ & $755 \cdot 7$ & $\mathrm{~B}_{2}$ & & \\
\hline 11 & 24 & $F$ & 6 & $\begin{array}{l}3 \cdot 50 \\
(94 \cdot 6)\end{array}$ & $\begin{array}{l}4 \cdot 86 \\
(108 \cdot 7)\end{array}$ & 0.57 & 0.50 & $724 \cdot 8$ & $1391 \cdot 7$ & $\mathbf{B}_{2}$ & & \\
\hline 12 & 37 & $\mathbf{M}$ & 4 & $\begin{array}{l}3.04 \\
(75.4)\end{array}$ & $\begin{array}{l}4 \cdot 53 \\
(88 \cdot 0)\end{array}$ & $0 \cdot 19$ & 0.13 & 999.4 & $1452 \cdot 9$ & $\mathbf{B}_{2}$ & & \\
\hline 13 & 29 & $\mathbf{M}$ & 9 & $\begin{array}{l}3.78 \\
(85 \cdot 5)\end{array}$ & $\begin{array}{l}5 \cdot 32 \\
(97 \cdot 3)\end{array}$ & $1 \cdot 25$ & $1 \cdot 31$ & 1594.9 & $2282 \cdot 3$ & $\mathbf{B}_{2}$ & & \\
\hline 14 & 43 & $\mathbf{M}$ & 1 & $\begin{array}{l}2 \cdot 99 \\
(84 \cdot 7)\end{array}$ & $\begin{array}{l}4 \cdot 31 \\
(93 \cdot 5)\end{array}$ & $4 \cdot 20$ & $2 \cdot 65$ & $>4610$ & $>4610$ & $\mathbf{B}_{2}$ & $T$ & B \\
\hline 15 & 21 & $\mathbf{F}$ & 2 & $\begin{array}{l}3 \cdot 20 \\
(96 \cdot 1)\end{array}$ & $\begin{array}{l}4 \cdot 15 \\
(107 \cdot 8)\end{array}$ & $4 \cdot 43$ & $4 \cdot 22$ & 867.6 & $1426 \cdot 7$ & $\mathbf{B}_{2}$ & & \\
\hline 16 & 40 & $\mathbf{M}$ & 1 & $\begin{array}{l}3.75 \\
(102 \cdot 2)\end{array}$ & $\begin{array}{l}4.78 \\
(101 \cdot 3)\end{array}$ & 6.73 & $3 \cdot 86$ & 1320.9 & $1221 \cdot 2$ & $\mathbf{B}_{2}$ & & \\
\hline 17 & 19 & $\mathbf{F}$ & 2 & $\begin{array}{l}3 \cdot 18 \\
(93 \cdot 0)\end{array}$ & $\begin{array}{l}3.68 \\
(94 \cdot 4)\end{array}$ & 1.08 & 0.86 & $1203 \cdot 7$ & $1224 \cdot 4$ & $\mathbf{B}_{2}$ & & \\
\hline 18 & 33 & $\mathbf{M}$ & 0 & $\begin{array}{l}3.47 \\
(101.8)\end{array}$ & $\begin{array}{l}4 \cdot 30 \\
(103 \cdot 4)\end{array}$ & 1.27 & 2.47 & $>4610$ & $>4610$ & $\mathbf{B}_{2}$ & & \\
\hline 19 & 21 & $\mathbf{M}$ & 9 & $\begin{array}{l}3.79 \\
(85 \cdot 5)\end{array}$ & $\begin{array}{l}4 \cdot 69 \\
(100 \cdot 0)\end{array}$ & 0.41 & 0.37 & $471 \cdot 5$ & $576 \cdot 2$ & $\mathbf{B}_{2}$ & & \\
\hline 20 & 18 & $\mathbf{F}$ & 12 & $\begin{array}{l}3.58 \\
(105 \cdot 5)\end{array}$ & $\begin{array}{l}4 \cdot 14 \\
(105 \cdot 6)\end{array}$ & $5 \cdot 54$ & $6 \cdot 1$ & 849.9 & 586.0 & $\mathbf{B}_{2}$ & & \\
\hline
\end{tabular}

symptoms were controlled by an inhaled $\beta_{2}$ agonist as required; five subjects were taking theophylline and four ipratropium bromide. Patients with a past history of cardiovascular disease, recent unstable asthma, or respiratory infection in the last month were excluded from the study. No subject was currently exposed to an antigen to which he was known to be sensitised. The study was approved by the hospital ethics committee and all subjects signed a consent form.

\section{STUDY DESIGN}

Subjects attended the laboratory on four occasions during two weeks. The visits were separated by at least 48 hours and tests were performed at the same time on each day. Long acting theophyllines were stopped for 48 hours, and inhaled adrenergic or anticholinergic drugs for eight hours before each test. Baseline FEV, had to be greater than $60 \%$ of predicted at each visit; if it was not, the test was postponed.
The initial evaluation included measurement of FEV , and forced vital capacity (FVC) with the vitalograph spirometer ( $\mathrm{S}$ model) and of bronchiab responsiveness to methacholine, by the method des? cribed by Cockcroft et al. On the three subsequente visits a methacholine inhalation test and two hyperos molar challenges were performed in a randomised, double blind order. After each test subjects were askeof to record the occurrence of respiratory symptoms.

METHACHOLINE INHALATION TESTS

After the measurement of baseline FEV, and FVC, the subject inhaled a control solution of saline $0.9 \%$ followed by doubling concentrations of methacholine $(0.03-8 \mathrm{mg} / \mathrm{ml})$ until a $20 \%$ fall in $\mathrm{FEV}_{1}$ occurred.0

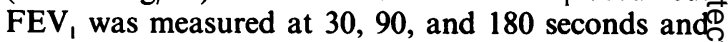
repeated if necessary every two minutes until it started to increase. Methacholine was inhaled for two minutes at five minute intervals, and the bronchial response 
expressed as the $\mathrm{PC}_{20} \mathrm{FEV}_{1}$ was obtained by interpolation of the last two points of the dose-response curve. Aerosols were generated by a Wright nebuliser operating at $345 \mathrm{kPa}\left(50 \mathrm{lb} / \mathrm{in}^{2}\right)$ and $71 \mathrm{~min}^{-1}$ to get a constant aerosol output of $0.13 \mathrm{ml} / \mathrm{min}^{-1}$.

\section{HYPEROSMOLAR CHALLENGES}

Aerosols of hyperosmolar saline were generated by a $\mathrm{MystO}_{2}$ gen ultrasonic nebuliser operating at $3.6 \mathrm{l}$ $\mathrm{min}^{-1}$ and calibrated to produce an aerosol output of 2.0 (SD 0.3 ) $\mathrm{ml} / \mathrm{min}$. Hyperosmolar saline was prepared by dilution of commercial sterile preservative free saline $3 \%$ or $14.6 \%$. A $20 \mathrm{ml}$ volume of each concentration of saline was placed in the nebuliser container in turn. Aerosols were inhaled via a mask held loosely over the face for periods of five minutes at five minute intervals, so that a total of $10 \mathrm{ml}$ of each concentration of saline was nebulised. If the fall in $\mathrm{FEV}_{1}$ was under $20 \%$ the next concentration was given five minutes later. After measurement of baseline $\mathrm{FEV}_{1}$ and FVC, subjects inhaled solutions of sodium chloride $0.9 \%, 1.8 \%, 3.6 \%, 7.2 \%$ and $14.4 \%$ as required; the solutions corresponded to osmolarities of $280,560,1062,2222$ and $4610 \mathrm{mmol}(\operatorname{mosm}) / \mathrm{kg}$. Osmolarity was measured with an osmometer MicroOsmette (Precisions Systems Inc, Massachusetts, Model 5004). Ionic concentration and density of hyperosmolar solutions measured before and after nebulisation were similar except for the last concentration $(14.4 \%)$, where there was a slight increase in density after nebulisation $(<10 \%$ of its initial density). The bronchial response was determined by measurement of $F E V_{1}$ at 30,90 , and 180 seconds after the inhalation and every two minutes until it started to increase. The test was stopped when a $20 \%$ fall in $\mathrm{FEV}_{\text {, }}$ was obtained or when the highest concentration of saline $(14.4 \%)$ had been given. The $\mathrm{PO}_{20}$, the osmolarity causing a $20 \%$ fall in $\mathrm{FEV}_{1}$, was determined by interpolation of the last two points of the log dose-response curve.

\section{TIME COURSE OF RESPONSE TO HYPEROSMOLAR CHALLENGE}

To determine the time course of hyperosmolar induced bronchoconstriction, FEV , was measured every two minutes for the first 15 minutes after the last inhalation of hyperosmolar saline and then every five minutes for one hour. If symptoms persisted after one hour, $200 \mu \mathrm{g}$ inhaled salbutamol was administered.

The peak action was defined as the maximum fall in $\mathrm{FEV}_{1}$ obtained after the last inhalation of hyperosmolar saline, and the plateau as the time the FEV remained within $10 \%$ of the peak value. The mean recovery time was the interval between the peak action and return of the FEV, to within $90 \%$ of baseline.

\section{STATISTICAL ANALYSIS}

All analyses were carried out on logarithmically transformed $\mathrm{PO}_{20}$ and $\mathrm{PC}_{20}$ values. Differences between the two $\mathrm{PO}_{20}$ saline and the two $\mathrm{PC}_{20}$ methacholine values were analysed with paired $t$ tests. The differences between the results of the two hyperosmolar challenges were plotted against their mean value to assess the repeatability of the tests. ${ }^{15}$ To determine whether $\mathrm{PC}_{20}$ methacholine was correlated with $\mathrm{PO}_{20}$ saline a linear regression analysis was performed.

\section{Results}

All 20 subjects studied completed the study. The responses to the challenges are summarised in table 2 . The side effects of hyperosmolar saline were similar to those of methacholine - transient cough, hypersecretion, and mild dyspnoea. After the study no increase in asthma symptoms or need to increase medication was reported apart from some continuing hypersecretion for a few hours after the osmolar challenge. Serum sodium concentrations, measured in four subjects after 10 minutes' inhalation of $14.4 \%$ saline, were unchanged.

A $\mathrm{PO}_{20}$ saline value was obtained in 16 of the 20 subjects; in the other four even the highest concentration $(14.4 \%)$ did not induce a fall in $\mathrm{FEV}_{1}$. Figure 1 shows the relation between the $\mathrm{PO}_{20}$ values from the two hyperosmolar tests. The difference in geometric mean $\mathrm{PO}_{20}$ values was not significant ( $\left.p>0.05\right)$. The

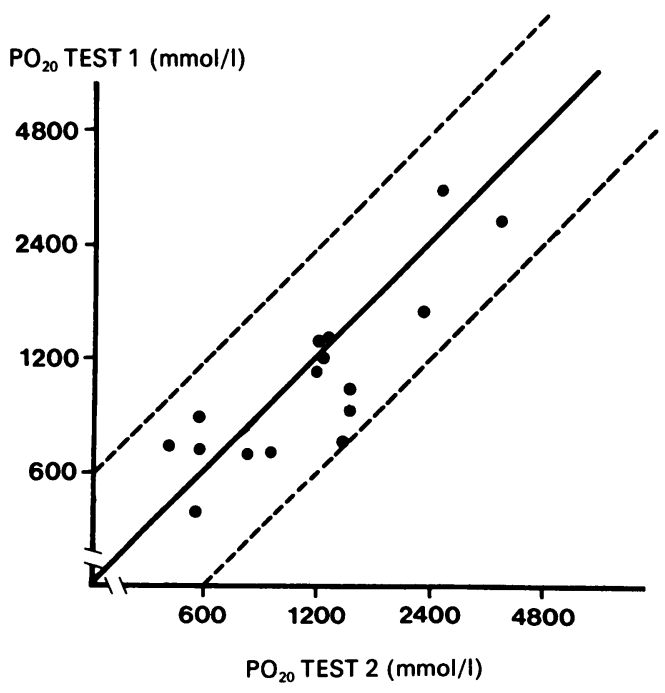

Fig 1 Bronchial response to hyperosmolar solutions in 16 subjects on two occasions (four had $<20 \%$ fall in FEV after $14.4 \%$ hyperosmolar saline). The solid line denotes the line of identity and the broken line a difference of one doubling osmolarity dose of saline. 


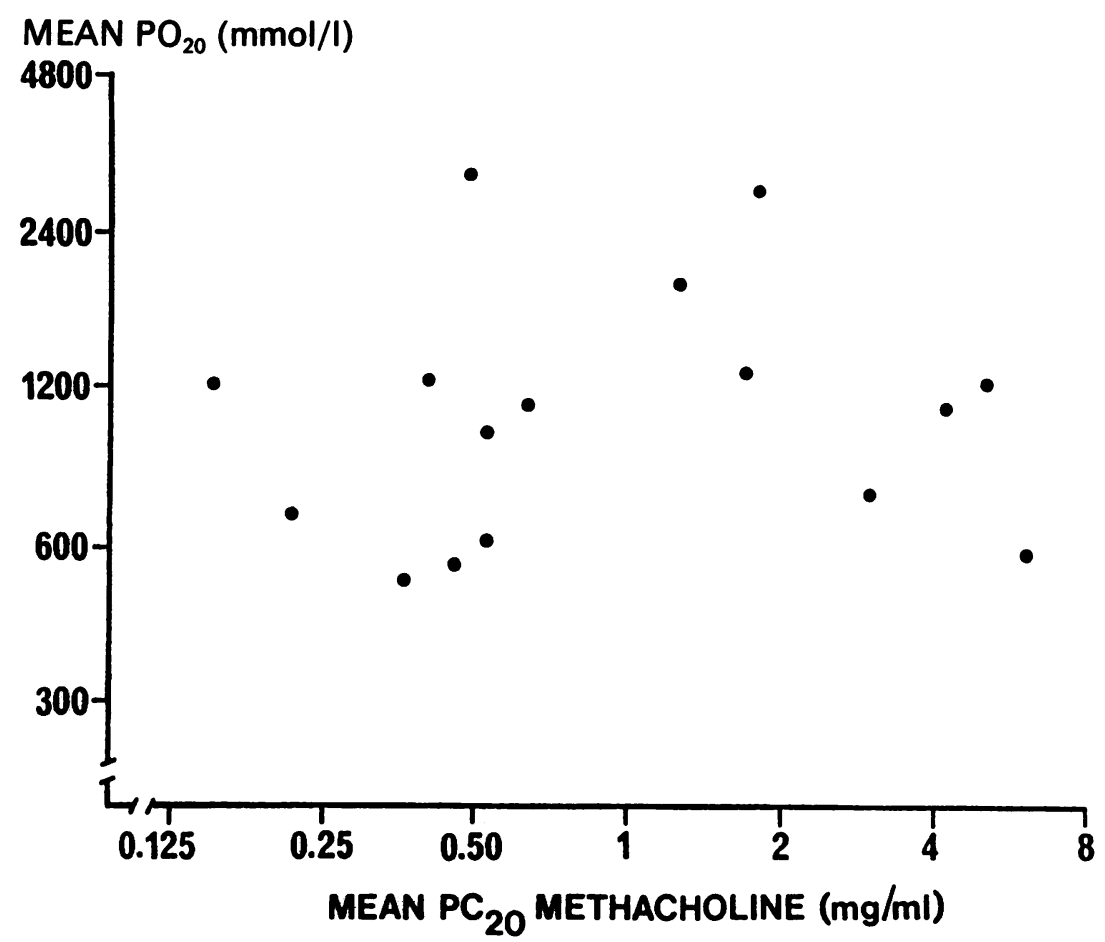

Fig 2 Mean $P O_{20}$ saline versus mean $P C_{20}$ methacholine in 16 subjects $(r=0 \cdot 168, p>0.05)$.

$\mathrm{PO}_{20}$ values were within one doubling osmolarity dose of saline for all 16 subjects. The difference in response to the two hyperosmolar challenges was not related to the mean $\mathrm{PO}_{20}$ value.

The response to methacholine inhalation, as expressed by the $\mathrm{PC}_{20}$ value, was repeatable. The $\mathrm{PC}_{20}$ values were within one doubling concentration of methacholine in 15 subjects and within two doubling concentrations in four subjects. One subject had only one test. There was no significant correlation between the mean $\mathrm{PC}_{20}$ methacholine and $\mathrm{PO}_{20}$ saline $(\mathrm{r}=0 \cdot 168$, $\mathrm{p}>0.05$; figure 2).

Figure 3 shows the pattern of change in $\mathrm{FEV}_{1}$ after hyperosmolar challenge. The peak action occurred at 3 minutes, the plateau duration was 17 minutes, the mean recovery time was 47 minutes, and the total duration of action was 50 minutes.

\section{Discussion}

In this study we used a new method to measure the bronchial responsiveness to hyperosmolar solutions in a dose-response manner. A $20 \%$ fall in $\mathrm{FEV}_{1}$ was obtained in $80 \%$ of the subjects after inhalation of hyperosmolar saline in concentrations up to $14.4 \%$. The different concentrations of saline represented substantial ionic change, sufficient to allow discrimin ation between the degrees of response to hyperosmolap saline among different asthmatic subjects. The test was simple, well tolerated, and reproducible. The degree of agreement found within one doubling dose for ale measurements is acceptable. In a further study some of these subjects have been rechallenged with hyperos molar saline by the same method and similar resultso have been obtained, confirming the reproducibility of the test. ${ }^{16}$ We did not test elderly patients or subjects? with cardiovascular disease. The amount of sodium chloride introduced into the airways is small, however and should not be harmful. Serum sodium concentraf tions were unchanged after inhalation of the highest concentration of saline.

We compared bronchial responsiveness to hyperos molar solutions and to methacholine. Methacholine challenges showed a good degree of reproducibilityo the $\mathbf{P C}_{20}$ values recorded being within a 3.2 fold concentration as reported previously. ${ }^{17}$

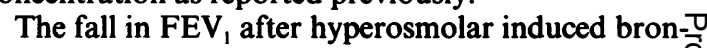
choconstriction was prolonged (50 minutes), an similar to the time course described for metha choline. ${ }^{18}$ In the few patients who required inhaled $B$ salbutamol $(200 \mu \mathrm{g})$ after the study the bronchoconi? striction was completely reversed. 


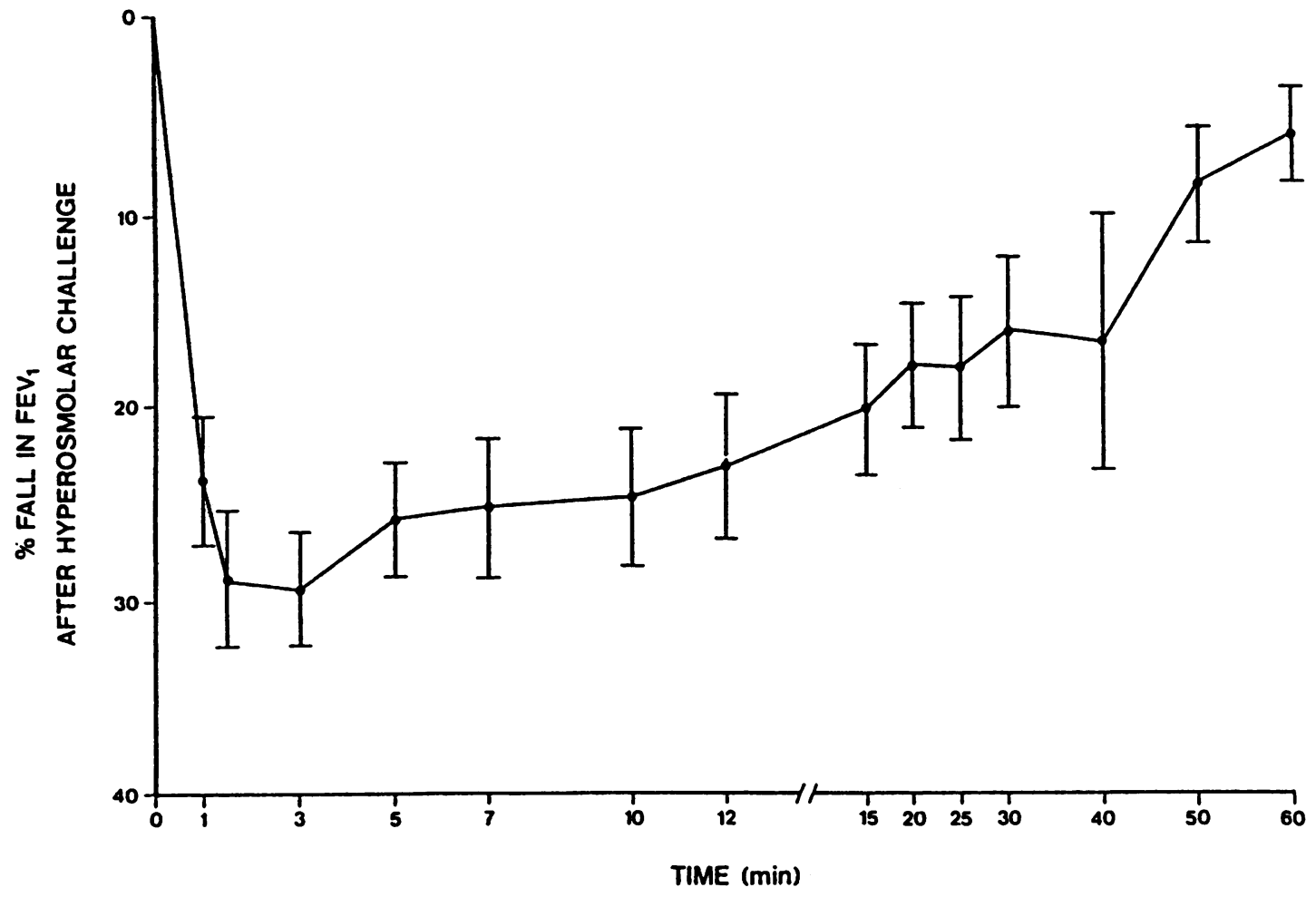

Fig 3 Mean (SEM) bronchoconstrictor response to hyperosmolar challenge in 16 subjects.

Our results confirm the findings of previous studies showing that inhalation of hyperosmolar solution causes bronchoconstriction in asthmatic subjects. ${ }^{3811}$ There was no correlation between the response to hyperosmolar solution and the response to methacholine. The hyperosmolar stimulus thus appears to differ from the other non-specific stimuli such as cold air, exercise, $\mathrm{PGF}_{2 \alpha}$, histamine, and methacholine since these have been shown to be correlated. ${ }^{91019}$

The response to methacholine and histamine has been shown to be related to the severity of asthma and the amount of medication required to control symptoms. ${ }^{20}$ This does not seem to be the case with hyperosmolar solutions, since there was no correlation between the $\mathrm{PO}_{20}$ and the severity of asthma, as assessed by baseline expiratory flow rates, medication needed to control asthma, or the $\mathrm{PC}_{20}$ methacholine. This suggests that the mechanism underlying the response to hyperosmolar solutions is different in the asthmatic population.

One of the main hypotheses to explain exercise induced asthma is that airway secretions become hyperosmolar during hyperventilation. ${ }^{6}$ We are therefore investigating the bronchial response to hyperosmolar saline and exercise. A correlation bet- ween the bronchial response to inhalation of hypoosmolar solution and exercise has been reported. ${ }^{12}$ Further studies are required to determine the consequences of airway dehydration in different situations and the role of mediators of inflammation in the development of bronchoconstriction induced by this stimulus.

In conclusion, we describe a new method of bronchoprovocation with hyperosmolar saline. This method is simple, reproducible, and safe. There was no correlation between the bronchial response to hyperosmolarity and the response to methacholine. This test may be of limited usefulness in the evaluation of non-specific bronchial reactivity or the degree of severity of asthma, but is an interesting tool to study the effect of osmolar changes in the airways, particularly in relation to exercise induced asthma.

This work was supported by a grant from the Medical Research Council of Canada.

\section{References}

1 Anderson SD, Schoeffel RE, Finney M. Evaluation of 
ultrasonically nebulized solutions for provocation testing in patients with asthma. Thorax 1983;38:284-91.

2 Allegra L, Bianco S. Non-specific broncho-reactivity obtained with an ultrasonic aerosol of distilled water. Eur J Respir Dis 1980;61 (suppl.) 106:41-9.

3 Schoeffel RE, Anderson SD, Altounyan REC. Bronchial hyperreactivity in response to inhalation of ultrasonically nebulized solutions of distilled water and saline. Br Med J 1981;283:1285-7.

4 Magyar P, Derwaderics M, Toth A. Bronchial challenge with hypertonic $\mathrm{KCI}$ solution in the diagnosis of bronchial asthma. A comparison with the challenge performed by inhalation of distilled water. Schweiz Med Wochenschr 1984;114:910-3.

5 Anderson SD, Schoeffel RE, Black JL, Daviskas E. Airway cooling as the stimulus to exercise-induced asthma - a reevaluation. Eur J Respir Dis 1985;67:2030.

6 Anderson SD. Is there a unifying hypothesis for exerciseinduced asthma? J Allergy Clin Immunol 1984;73:660-5.

7 Findlay SR, Dvorak AM, Kagey-Sobotka A, Lichtenstein LM. Hyperosmolar triggering of histamine release from human basophils. J Clin Invest 1981;67:1604-13.

8 Eschenbacker WH, Boushey HA, Sheppart D. Alteration in osmolarity of inhaled aerosol cause bronchoconstriction and cough, but also absence of a permanent avion causes cough alone. Am Rev Respir Dis 1984;129:211-5.

9 Anderton RC, Cuff MT, Frith PA et al. Bronchial responsiveness to inhaled histamine and exercise. $J$ Allergy Clin Immunol 1979;63:315-21.

10 O'Byrne PM, Ryan G, Morris M, et al. Asthma induced by cold air and its relation to non-specific bronchial responsiveness to methacholine. Am Rev Respir Dis 1982;125:281-5.

11 Fabbri LM, Mapp CE, Hendrick DJ. Comparison of ultrasonically nebulized distilled water and hyperveng tilation with cold air in asthma. Ann Allerg 1984;53:172-7.

12 Bascom R, Bleecker ER. Bronchoconstriction induced bo distilled water. Am Rev Respir Dis 1986;134:248-53.

13 American Thoracic Society. Definitions and Classifica tion of chronic bronchitis, asthma and pulmonarb emphysema. Am Rev Respir Dis 1962;85:762-8.

14 Cockcroft DW, Killian DN, Mellon JJA, Hargreave FE. Bronchial reactivity to inhaled histamine: a method ang clinical survey. Clin Allergy 1977;7:235-43.

15 Bland JM, Altman DG. Statistical methods for assessin agreement between two methods of clinical measurement. Lancet 1986;i:307-10.

16 Turcotte H, Boulet LP. Bronchial reactivity to hyperos molar saline in asthmatics: a comparison with thæ response to methacholine and exercise. J Allergy Clm Immunol 1987;79:148.

17 Dehaut P, Rachiele A, Martin RR, Malo JL. Histamine dose-response curves in asthma: reproducibility ang sensitivity of different indices to assess response. Thora 1983;38:516-22.

18 Cartier A, Malo JL, Bégin P, Sestier M, Martin RR. Tim course of the bronchoconstriction induced by inhaled histamine and methacholine. $J$ Appl Physi@ 1983;54:821-6.

19 Thomson NC, Roberts R, Bandouvakis J, Newball th Hargreave FE. Comparison of bronchial responses prostaglandin $\mathrm{F}_{2} \mathrm{a}$ and methacholine. $J$ Allergy $\mathrm{Cl}$ Immunol 1981;68:392-99.

20 Hargreave FE, Ryan G, Thomson NC, O'Byrne PMD Latimer K, Juniper EF, Dolovich J. Bronchial respon siveness to histamine or methacholine in asthm measurement and clinical significance. $J$ Allergy $C l$ in Imunol 1981;68:347-55. 